\title{
Reproductive cycle progression arrest and modification of cell morphology (shape and biovolume) in the alga Pseudokirchneriella subcapitata exposed to metolachlor
}

\author{
Manuela D. Machado $^{\mathrm{a}, \mathrm{b}, *}$, Eduardo V. Soares ${ }^{\mathrm{a}, \mathrm{b}, *}$ \\ ${ }^{a}$ Bioengineering Laboratory-CIETI, ISEP-School of Engineering, Polytechnic Institute of Porto, Rua Dr António Bernardino de Almeida, 431, $4249-015$ Porto, Portugal \\ ${ }^{\mathrm{b}}$ CEB-Centre of Biological Engineering, University of Minho, Campus de Gualtar, 4710-057 Braga, Portugal
}

\section{A R T I C L E I N F O}

\section{Keywords:}

Biovolume

Cell growth

Esterase activity

Herbicide

Metolachlor toxicity

Photosynthesis

\begin{abstract}
A B S T R A C T
Metolachlor (MET) is an herbicide widely used and frequently found (at $\mu \mathrm{g} \mathrm{L}^{-1}$ ) in aquatic systems. This work aimed to study the modes of action of MET on the green microalga Pseudokirchneriella subcapitata. Algae exposed to 115 or $235 \mu^{-1} \mathrm{MET} \mathrm{L}^{-1}$, for 48 or $72 \mathrm{~h}$, presented a reduction of metabolic activity, chlorophyll $a$ and $b$ content and photosynthetic efficiency. The exposure to 115 or $235 \mu \mathrm{g} \mathrm{L}^{-1} \mathrm{MET}$ also induced growth yield reduction, mean cell biovolume increase and alteration of the typical algae shape (cells lunate or helically twisted) to "French croissant"-type; at these MET concentrations, algal population was mainly composed by multinucleated cells ( $\geq 4$ nuclei), which suggest that MET impairs the normal progression of the reproductive cycle but did not hinder nuclear division. The accumulation of multinucleated cells seems to be the consequence of the incapacity of the parent cell to release the autospores. In conclusion, MET disrupts the physiology of $P$. subcapitata cells; the disturbance of the progression of the reproductive cycle should be in the origin of growth slowdown (or even its arrest), increase of mean cell biovolume and modification of algal shape. This work contributed to elucidate, in a systematically and integrated way, the toxic mechanism of MET on the non-target organism, the alga $P$. subcapitata.
\end{abstract}

\section{Introduction}

In the last decades of the $20^{\text {th }}$ century, herbicides were widely applied in agriculture to combat undesirable vegetation and increase crop production having as consequence their dissemination in the environment. Nowadays, there are undeniable evidences that these compounds may pose serious risks to non-target organisms and unwanted side effects to the soil and aquatic environment (Jurado et al., 2011).

Metolachlor (MET) is a commonly used chloroacetamide herbicide which is applied to control broadleaf and annual grass weeds in corn, soybean, peanut and potato (Rivard, 2003). This herbicide is absorbed through the plant roots and shoots and acts as a growth inhibitor of weeds interfering with different enzymes and restraining the synthesis of chlorophyll, proteins, lipids, isoprenoids and flavonoids (Singh and Singh, 2016). The growth of weeds is blocked after the germination through impairment of cell division (Deal and Hess, 1980). The mechanism of action of MET in plants involves the blockage of very long chain fatty acids (VLCFA) formation (Deal and Hess, 1980), due to the inhibition of the very-long-chain 3-oxoacyl-CoA synthase (encoded by FAE1 gene), a starter enzyme required for the elongation of $\mathrm{C}_{16}$ and $\mathrm{C}_{18}$ to $C_{20}$ fatty acids (Götz and Böger, 2004).

MET is drained from soil to aquatic systems, where it is highly soluble and presents a half-life of over 200 days (Kollman and Segawa, 1995) making it a persistent compound (Liu et al., 1995). It is regularly detected in US (Battaglin et al., 2000; Rivard, 2003) and Europe waters (Roubeix et al., 2012; Lopez et al., 2015; Székács et al., 2015) in concentrations from ng L ${ }^{-1}$ to several hundreds of $\mu \mathrm{g} \mathrm{L}^{-1}$ (US-EPA, 2019; Woodward et al., 2019) The frequent detection of MET in water sources forced the United States Environmental Protection Agency (US-EPA) to establish a lifetime health advisory level of $100 \mu \mathrm{g} \mathrm{L}^{-1}$ for drinking water (US-EPA, 1995).

The contamination of aquatic ecosystems with herbicides is an emerging concern issue as they can affect several levels of biological organization, from molecular to ecosystem level (Pereira et al., 2009). MET toxicity has been reported to aquatic organisms as cyanobacteria (Chen et al., 2019), algae (Fairchild et al., 1998; Ebenezer and Ki, 2013;

\footnotetext{
* Corresponding authors at: Bioengineering Laboratory-CIETI, ISEP-School of Engineering, Polytechnic Institute of Porto, Rua Dr António Bernardino de Almeida, 431, 4249-015 Porto, Portugal.

E-mail addresses: mmmachado@net.sapo.pt (M.D. Machado), evs@isep.ipp.pt (E.V. Soares).
} 
Thakkar et al., 2013; Deng et al., 2015), aquatic plants (Diepens et al., 2017), crustaceans (Maazouzi et al., 2016; Velisek et al., 2019) and fishes (Quintaneiro et al., 2017).

Algae are primary producers and the first level of aquatic food chain providing initial nutrients and energy to all aquatic ecosystem; any effect on algae will have impact on higher trophic levels (Campanella et al., 2001). Previous studies showed that MET cause several adverse effects in green algae, namely growth inhibition, photosynthesis disturbance, cell size alterations, membrane permeabilization and oxidative stress (Liu and Xiong, 2009; Liu et al., 2017; Spoljaric et al., 2011). Therefore, it was described a decrease in chlorophylls ( $a$ and $b$ ) production in the algae Chlorella pyrenoidosa (Liu and Xiong, 2009) and Scenedesmus obliquus (Liu et al., 2017), after a 96h-exposure to MET. Algal cells of Scenedesmus vacuolatus (Vallotton et al., 2008; Copin et al., 2016) and Chlamydomonas reinhardtii (Korkaric et al., 2015) exposed to 900,3200 and $450 \mu \mathrm{g} \mathrm{L}^{-1}$ of MET, respectively, presented an enlargement of their size.

Pseudokirchneriella subcapitata is a microalga with an ubiquitous distribution, being recommended for freshwater toxicity studies by Organization for Economic Co-operation and Development (OECD) (OECD, 2011) and the US-EPA (US-EPA, 2012a). Probably, due to the fact that ecotoxicological assessment of chemicals, for regulatory purposes, is based on algal growth inhibition, almost no information can be found in the literature regarding the mode of action (MoA) of MET on $P$. subcapitata.

The green alga phylum comprises a large and diverse group of organisms. Some studies with green alga genera revealed distinct sensitivity of the organisms to MET. Thus, $72 \mathrm{~h}-\mathrm{EC}_{50}$ values of $81-1090 \mu \mathrm{g}$ $\mathrm{L}^{-1}$ for Chlorella (Liu and Xiong, 2009; Maronic et al., 2018), 44.3-115 $\mathrm{\mu g} \mathrm{L}^{-1}$ for Pseudokirchneriella (Machado and Soares, 2019a; Pérez et al., 2011; Sbrilli et al., 2005; Souissi et al., 2013) and 57,100 $\mu \mathrm{g}$ $\mathrm{L}^{-1}$ for Scenedesmus were described (US-EPA, 2012b). This different sensitivity of microalgae to MET can be the consequence of different cell macromolecular composition (namely, lipids type and content and cell wall composition), different intracellular targets of MET or differences in the activation of defence mechanisms. This means that the information found in the literature for few green alga genera/species cannot be generalized for the whole phylum. Taking into account the ecotoxicological relevance of $P$. subcapitata, it is of particular importance the knowledge of the physiological effects of MET on this microalga. These information can be useful in the: i) search of new and more sensitives endpoints for toxicity assessment of chemicals; ii) development of theoretical models, mechanistically-based, for predicting algal growth inhibition $\left(\mathrm{EC}_{50}\right.$ ) after chemicals exposure; iii) synthesis of new herbicides with lower environmental impacts.

The present study aimed to investigate the effects of MET on the alga $P$. subcapitata. For this purpose, cells were exposed at environmentally relevant MET levels $\left(\mu \mathrm{g} \mathrm{L}^{-1}\right)$ for $72 \mathrm{~h}$ and the impact of the herbicide was evaluated, at different exposure times, using the following endpoints: growth, morphology (biovolume and cell shape), reproductive-cycle progression, chlorophyll $a$ and $b$ concentration, photosynthetic and metabolic activity. The possible mechanisms through which MET exerts a toxic effect on a non-target organism, the green alga $P$. subcapitata, will be discussed. As far as we know, this is the first work which studies, in an integrated way, the toxicity of MET on $P$. subcapitata.

\section{Material and methods}

\subsection{Test organism and culture conditions}

This study was carried out with the unicellular microalga Pseudokirchneriella subcapitata (strain 278/4) from the Culture Collection of Algae and Protozoa (CCAP, UK). P. subcapitata was maintained in OECD medium (OECD, 2011) with $2 \%(\mathrm{w} / \mathrm{v})$ of agar and stored in the dark, at $4{ }^{\circ} \mathrm{C}$. $P$. subcapitata cultures, in exponential phase of growth (2 days culture), were obtained by inoculating $100 \mathrm{~mL}$ of OECD medium (in $250 \mathrm{~mL}$ Erlenmeyer flasks) with $\sim 5 \times 10^{4}$ cells $\mathrm{mL}^{-1}$; cultures were incubated at $25^{\circ} \mathrm{C}$, on an orbital shaker at $100 \mathrm{rpm}$, under continuous light provided by "cool white" fluorescent lamps (colour temperature of $4300 \mathrm{~K}$ ), with an intensity of 4000 lux at the surface of the flasks, as previously described (Machado and Soares, 2012).

\subsection{Exposure of algal cells to MET}

Algal cells $\left(5 \times 10^{4}\right.$ cells $\left.\mathrm{mL}^{-1}\right)$, in exponential phase of growth, were inoculated in $1 \mathrm{~L}$ Erlenmeyer flasks containing OECD medium and MET in a final volume of $400 \mathrm{~mL}$. MET stock solution $\left(11.8 \mathrm{mg} \mathrm{L}^{-1}\right)$ was prepared in water and stored in the dark, at $4{ }^{\circ} \mathrm{C}$. Algae were incubated with four MET concentrations: $40 \mu \mathrm{g} \mathrm{L}{ }^{-1}$, for which no growth inhibition occurs (72h-no observed effect concentration, NOEC), $45 \mu \mathrm{g} \mathrm{L} \mathrm{L}^{-1}$, $115 \mu \mathrm{g} \mathrm{L}^{-1}$ and $235 \mu \mathrm{g} \mathrm{L}^{-1}$, which correspond to $72 \mathrm{~h}-\mathrm{EC}_{10}$, $72 \mathrm{~h}-\mathrm{EC}_{50}$ and $72 \mathrm{~h}-\mathrm{EC}_{90}$ values. MET effect concentrations were previously determined by the OECD 72-h growth inhibition test using 8 MET concentrations, in a geometric series, ranging from 16 to $400 \mu \mathrm{g} \mathrm{L}^{-1}$ (Machado and Soares, 2019a). As control, algal cells were inoculated in OECD medium without herbicide. Control and MET assays were run for $72 \mathrm{~h}$, in the same incubation conditions described to obtain the inoculum (Section 2.1).

After 24,48 and $72 \mathrm{~h}$ of incubation, cells were withdrawn, centrifuged ( $2500 \mathrm{x} g, 5 \mathrm{~min}$ ) and resuspended in OECD medium. Then, the effects of MET on the alga $P$. subcapitata were assessed using different endpoints.

For growth kinetic studies, five independent experiments were performed and algal cell concentration was measured, in quintuplicate, using an automatic cell counter (TC10, Bio-Rad).

\subsection{Biovolume determination}

Biovolume of algal cells were accessed as previously described (Machado and Soares, 2014). Photos of non-treated (control) and METtreated algal cells were randomly acquired using a phase-contrast microscope, equipped with a N plan X100 objective coupled with a Leica DC $300 \mathrm{~F}$ camera. Photos were processed using a Leica IM 50-Image manager software. Three independent experiments were performed and at least 300 cells were analysed, for each MET concentration, at each time. Thus, for each MET concentration $\geq 900$ cells were examined. Biovolume was calculated assuming that algal cells of $P$. subcapitata generally present the form of a sickle-shaped cylinder (Sun and Liu, 2003). Cell biovolume (V) is defined as:

$\mathrm{V} \approx(\pi / 6) \cdot a \cdot b^{2}$

where $a$ and $b$ are cell apical section view (length) and transapical section (width), respectively.

\subsection{Reproductive-cycle progression analysis}

The distribution of algal cells among the reproductive cycle was monitored as previously described by Machado and Soares (2014). Cells suspended in OECD medium at $3 \times 10^{6}$ cells $\mathrm{mL}^{-1}$ were treated with 1 pentanol $(70 \%, \mathrm{v} / \mathrm{v})$ for $1 \mathrm{~h}$, to permeabilize cell membrane. Then, cells were incubated with $0.5 \mu \mathrm{mol} \mathrm{L}^{-1}$ SYTOX Green for $40 \mathrm{~min}$, in the dark, at $25{ }^{\circ} \mathrm{C}$ and observed using an epifluorescence microscope, equipped with an HBO-100 mercury lamp and filter set GFP from Leica. Images were acquired and processed as described above. For each concentration, at least 100 cells were analysed in randomly selected microscope fields. This experiment was independently repeated four times; a total of $\geq 400$ cells were analysed in control or each MET concentration, at each time point. 

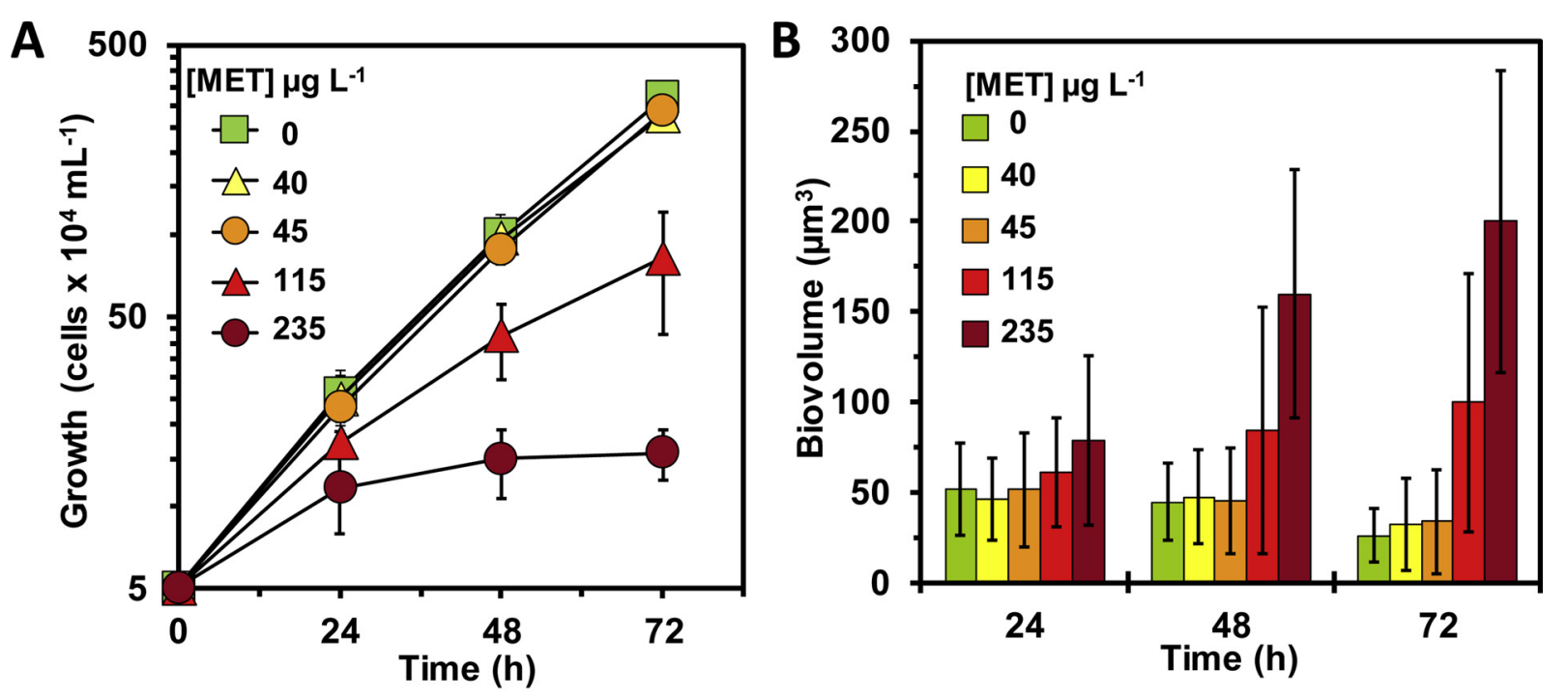

C

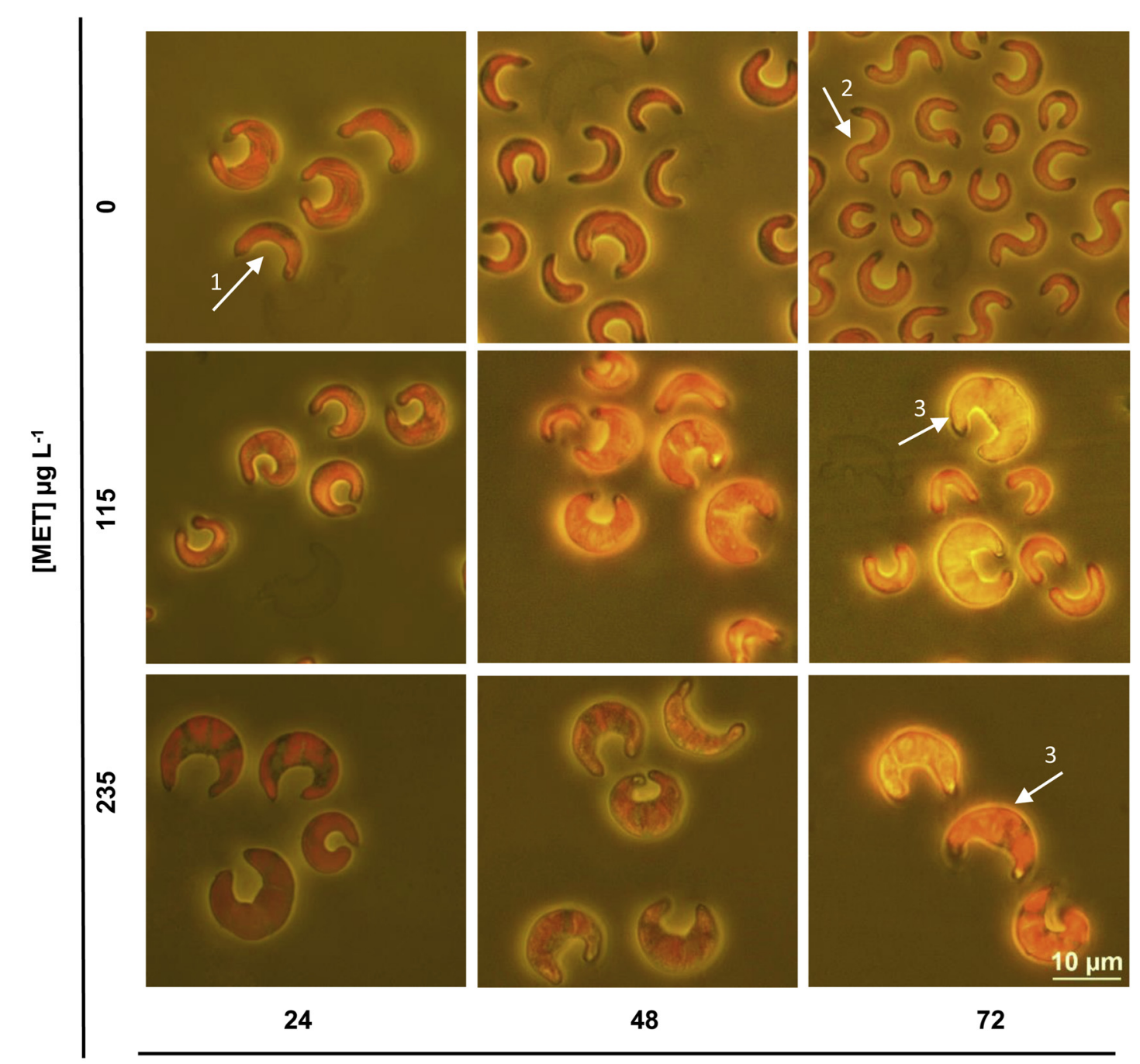

Time (h)

Fig. 1. Consequence of MET on cell proliferation and morphology of $P$. subcapitata. Algal cells were inoculated in OECD medium in the absence (control) or in presence of different MET concentrations. A - Evolution of algal growth; B - Algal biovolume. A and B: the error bars represent the SD. C - Visualization of the impact of MET concentration and exposure time on algal morphology; fluorescence plus phase contrast images of algal cells. Arrow 1: lunate cells; arrow 2: helically twisted cells; arrow 3: flattened "French croissant"-type cells. 


\subsection{Determination of chlorophyll content and photosynthetic activity}

The determination of the content of chlorophyll $a$ (Chl $a$ ) and $b$ (Chl b) was performed as previously described by Soto et al. (2011). Algae, at $3 \times 10^{6}$ cells $\mathrm{mL}^{-1}$, were treated with $90 \%(\mathrm{v} / \mathrm{v})$ of acetone, in triplicate, for $20 \mathrm{~h}$, at $4{ }^{\circ} \mathrm{C}$, in the dark. Then, cells were centrifuged $(2500 \times \mathrm{g}, 10 \mathrm{~min})$ and the absorbance of the supernatant was measured at 630, 647, 664 and $691 \mathrm{~nm}$. Absorbance was corrected (for turbidity) by subtracting the value of absorbance at $750 \mathrm{~nm}$. Chl $a$ and $b$ content was calculated as described by Ritchie (2008). Each of five independent experiments were performed in triplicate. The results were normalised considering algal biovolume and the impact of MET was expressed as the ratio of chlorophyll in the assay/chlorophyll in the control (cells not exposed to MET).

Photosynthetic activity was evaluated by pulse amplitude modulation (PAM) fluorometry using a junior PAM fluorometer (Walz,

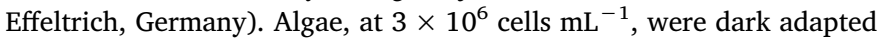
for $30 \mathrm{~min}$ for maintain all photosystem II (PSII) reaction centres open; the minimal fluorescence $\left(\mathrm{F}_{0}\right)$ and the maximum fluorescence $\left(\mathrm{F}_{\mathrm{m}}\right)$ yield were measured (tenfold) and the maximum photochemical quantum yield of PSII $\left(\mathrm{F}_{\mathrm{v}} / \mathrm{F}_{\mathrm{m}}\right)$ was automatically calculated using the WinControl software (version 3.2.2) (Maxwell and Johnson, 2000). Then, dark adapted algal cells were illuminated by an actinic light (for closing all PSII centres) at an intensity of $190 \mu \mathrm{mol} \mathrm{m}^{-2} \mathrm{~s}^{-1}$ and the minimum and the maximum fluorescence in the light $\left(\mathrm{F}_{0}{ }_{0}\right.$ and $\mathrm{F}_{\mathrm{m}}$, respectively) were determined tenfold. These parameters were used to calculate the effective photochemical quantum yield of PSII $\left(\Phi_{\mathrm{PSII}}\right)$, the relative electron transport rate (ETR) and the non-photochemical quenching (NPQ) (Maxwell and Johnson, 2000), using the WinControl software; the equations for each parameter is described in Table S1 of the Supplementary Material. This experiment was independently repeated three times. The impact of MET on photosynthetic activity of the alga $P$. subcapitata was expressed, for each parameter determined, as the ratio between value in the assay and the value in the control.

\subsection{Estimation of esterase activity}

Esterase activity was evaluated using the fluorescein diacetate (FDA) hydrolysis assay described by Machado and Soares (2013). After exposure to MET, algal cells $\left(5 \times 10^{5}\right.$ cells $\left.\mathrm{mL}^{-1}\right)$ were incubated, in quintuplicate, with $20 \mu \mathrm{mol} \mathrm{L}{ }^{-1}$ FDA (Sigma-Aldrich) in the dark, at $25^{\circ} \mathrm{C}$, for $40 \mathrm{~min}$. Positive (cells not exposed to MET) and negative controls - without esterasic activity (heat treated cells at $65^{\circ} \mathrm{C}$, for $1 \mathrm{~h}$ ) were also used. This experiment was independently performed five times.

The influence of MET in FDA hydrolysis or fluorescein fluorescence was evaluated. For this purpose, abiotic controls (without cells) with different concentrations of MET and FDA or fluorescein were also performed as previously reported (Machado and Soares, 2019b).

The fluorescence intensity of samples and controls was measured, in quintuplicate, in a Perkin-Elmer microplate reader (Victor3) at a fluorescence excitation wavelength of $485 / 14 \mathrm{~nm}$ and an emission wavelength of $535 / 25 \mathrm{~nm}$. Fluorescence was corrected (subtracting cell, culture medium and dye fluorescence) and normalised considering the mean algal biovolume in each MET concentration or control. The results were expressed as the ratio of fluorescence of the assay/fluorescence of the control (cells not exposed to MET).

\subsection{Reproducibility of the results and statistical analysis}

All experiments were repeated, independently, three to five times as reported above. The data presented are the mean \pm standard deviation. In Figs. 2A, 3, 4 and 5, the statistical difference between control and MET treated algal cells were tested using unpaired $t$ test; $P$ values $<0.05$ were considered statistically significant.

\section{Results}

3.1. MET inhibits growth, increases cell size and modifies the shape of $P$. subcapitata

The MoA of MET in susceptible plants (its target) is by interfering with normal cell development, through the inhibition of cell division and elongation (Rose et al., 2016). The presence of this herbicide in aquatic environments makes it extremely important to consider the evaluation of their impact on non-target organisms, such as algal cells.

Thus, this study started with the assessment of the impact of environmentally relevant MET concentrations (40-235 $\mu \mathrm{g} \mathrm{L}^{-1}$ ) on algal growth, over time (growth kinetics) (Fig. 1A). Algal cells exposed to 40 and $45 \mu \mathrm{g} \mathrm{L}{ }^{-1}$ MET maintained a growth pattern similar to the control. A slowdown $\left(115 \mu \mathrm{g} \mathrm{L}^{-1}\right)$ or even an algal growth arrest $\left(235 \mu \mathrm{g} \mathrm{L}^{-1}\right)$ was observed after the exposure for $24 \mathrm{~h}$ to the herbicide (Fig. 1A).

An assessment of the impact of MET on P. subcapitata morphology [cell size (biovolume) and shape] was carried out by microscopy image analysis. At MET concentrations $\leq 45 \mu \mathrm{g} \mathrm{L}^{-1}$ no appreciable modification in cell size was observed, over time (Fig. 1B). Algal cells exposed to MET concentrations of $115 \mu \mathrm{g} \mathrm{L}^{-1}$ or $235 \mu \mathrm{g} \mathrm{L} \mathrm{L}^{-1}$ displayed an increased mean cell volume. This effect was accentuated with the increase of MET concentration and exposure time to the herbicide (Fig. 1B and C). Cells exposed to $235 \mu \mathrm{L} \mathrm{L}^{-1}$ MET presented a mean biovolume of 79, 160, $200 \mu \mathrm{m}^{3}$ after 24,48 and $72 \mathrm{~h}$, respectively. In all cases, a large dispersion of the biovolume was observed (represented by big standard deviations - error bars), reflecting the heterogeneity of the algal populations.

In control (in the absence of the toxicant) it was possible to observe the typical $P$. subcapitata shape, throughout the growth: cells lunate (Fig. 1C, arrow 1) or helically twisted (Fig. 1C, arrow 2) with pointed to round ends. Algal cells exposed to $115 \mu \mathrm{g} \mathrm{L} \mathrm{L}^{-1}$ or $235 \mu \mathrm{g} \mathrm{L} \mathrm{L}^{-1}$ MET presented a flattened "French croissant" shape (Fig. 1C, arrow 3). In algae exposed to $115 \mu \mathrm{g} \mathrm{L}^{-1} \mathrm{MET}$, it was possible to observe both shapes (lunate and "croissant"-type); in cells exposed to $235 \mu \mathrm{g} \mathrm{L}^{-1} \mathrm{MET}$, the "French croissant" is the predominant shape (Fig. 1C). The drift from lunate to "croissant"-type shape accentuated with the increase of herbicide concentration.

\subsection{MET affects algae reproductive cycle by impairing the release of autospores}

P. subcapitata is a unicellular alga that reproduces asexually by autospores (structures produced within the parent cell and presenting the same shape as the parent), being possible to differentiate 4 stages in their reproductive cycle: 1 ) cells with one nucleus and typical shape (stage 1); 2) increase of the cells size (stage 2); 3) first nuclear division; after division, cells with two nuclei can be observed (stage 3) and 4) second nuclear division (where cells present 4 nuclei, stage 4), followed by the release of the four autospores (Van den Hoek et al., 1997; Machado and Soares, 2014).

P. subcapitata algal cells, not exposed to MET (control), were mainly (57-66\%) in stage 1, with one nucleus, during the 72-h growth (Fig. 2A, C); a similar distribution of cells in the different stages was observed for algae exposed to $45 \mu \mathrm{g} \mathrm{L}{ }^{-1}$ MET (data not shown). Cells treated with 115 or $235 \mu \mathrm{g} \mathrm{L}^{-1} \mathrm{MET}$, for $24-48 \mathrm{~h}$, were mostly (47-54 $\%$ ) in stage 4, with 4 nuclei (Fig. 2A). Interestingly, algae cultures exposed to $\geq 115 \mu \mathrm{g} \mathrm{L}^{-1}$ MET presented cells with more than 4 nuclei (Fig. 2C, arrow), which was not observed in control (not exposed to MET) or in cultures exposed to $45 \mu \mathrm{g} \mathrm{L}^{-1}$ MET. The percentage of cells with $>4$ nuclei increased with herbicide concentration and exposure time (Fig. 2B). Thus, algal cell population incubated with 115 or $235 \mu \mathrm{g}$ $\mathrm{L}^{-1}$ MET, for $72 \mathrm{~h}$, presented $\sim 30$ and $70 \%$ of cells with more than 4 nuclei, respectively (Fig. 2B); under these conditions, the cell populations are mainly composed ( 58 or $94 \%$, respectively) by multinucleated cells (i.e., with $\geq 4$ nuclei) (Fig. S1). These results suggest that MET did 

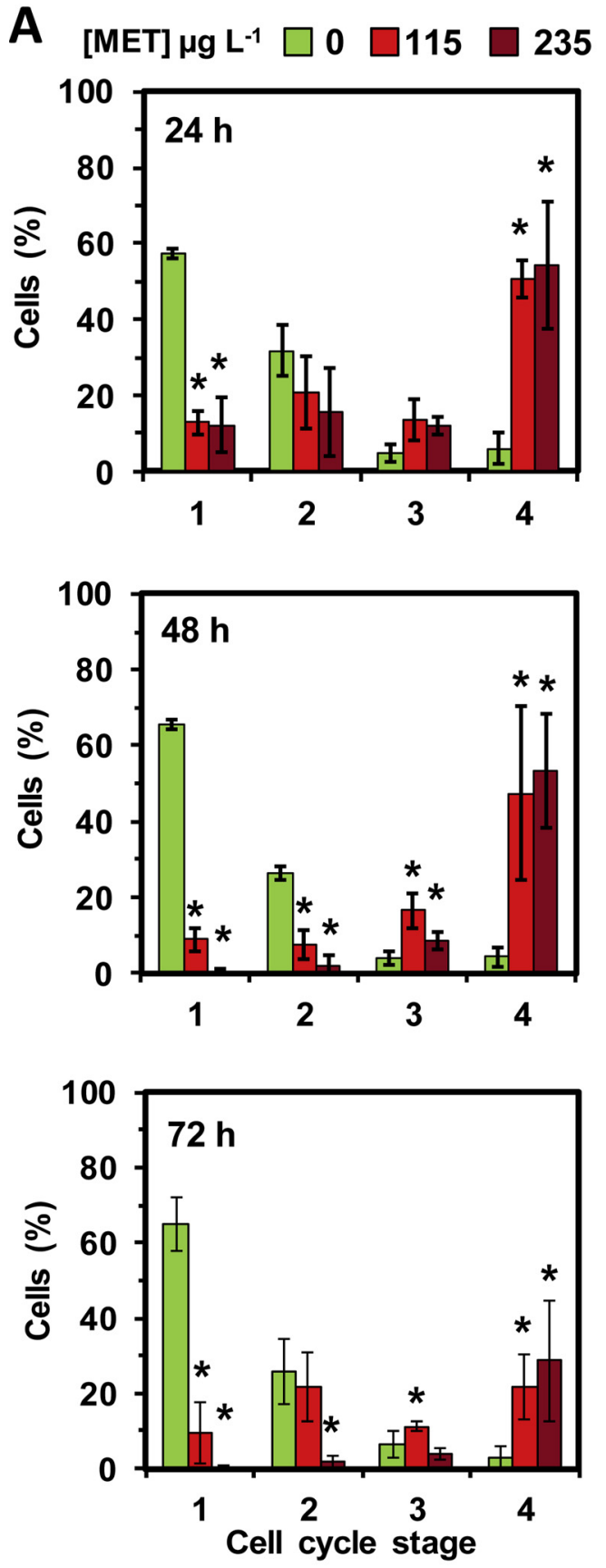

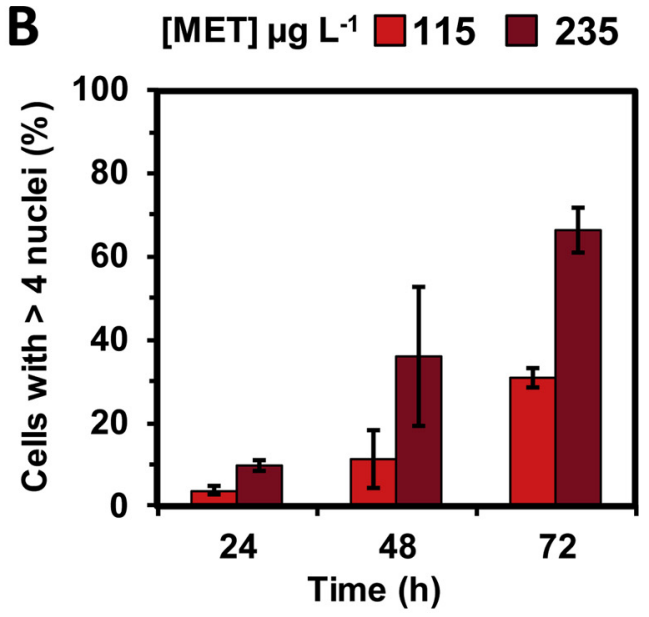

C

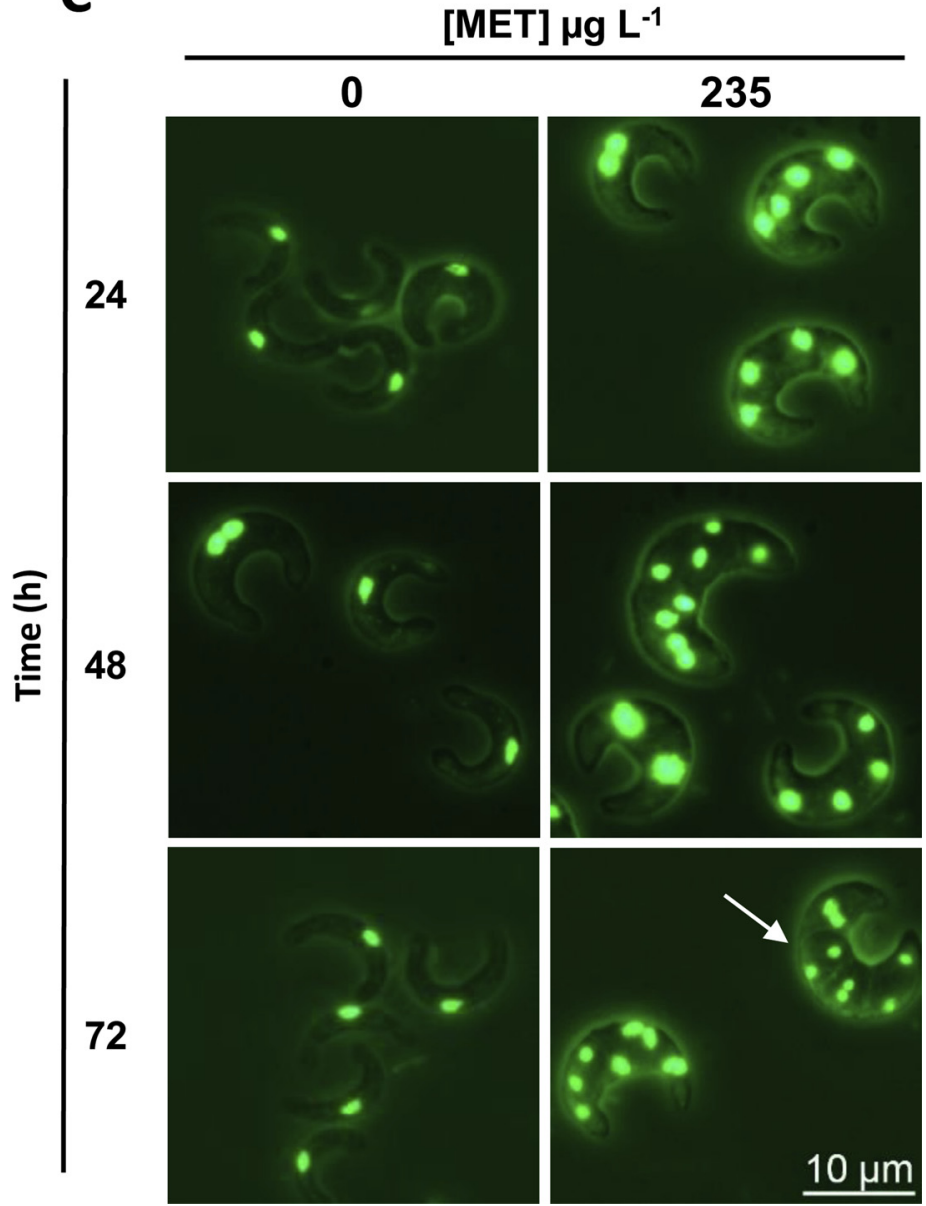

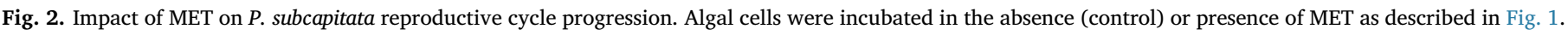

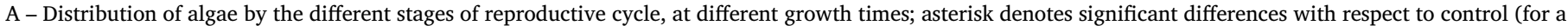

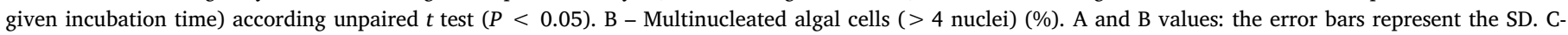
Fluorescence plus phase contrast images of algal cells treated with MET; arrow: multinucleated cell (8 nuclei).

not impair nuclear division of algal cells. The progression in the normal reproductive cycle was stopped, most likely, due to the incapacity of the parent cell release the autospores. In fact, cells with an abnormal number of nuclei $(>4)$ could be observed when algal culture was treated with $\geq 115 \mu \mathrm{g} \mathrm{L}^{-1}$ of herbicide (Fig. $2 \mathrm{~B}$ and C).

Taken together, the results presented suggest that algae exposed to MET concentrations $\geq 115 \mu \mathrm{g} \mathrm{L}{ }^{-1}$ exhibit the arrest of the reproductive cycle, which may originate the increase of mean cell biovolume (Fig. 1B and $\mathrm{C}$ ).

\subsection{MET reduces photosynthetic pigments concentration and photosynthetic efficiency}

The herbicide MET was designed to control the growth of undesirable plants. Algae present many similarities with plants, namely the photosynthetic capacity. The effect of MET on algal photosynthetic activity was assessed by the quantification of $\mathrm{Chl} a$ and $b$ pigments and by the evaluation of the functionality of PSII through the PAM fluorescence assay. 
A
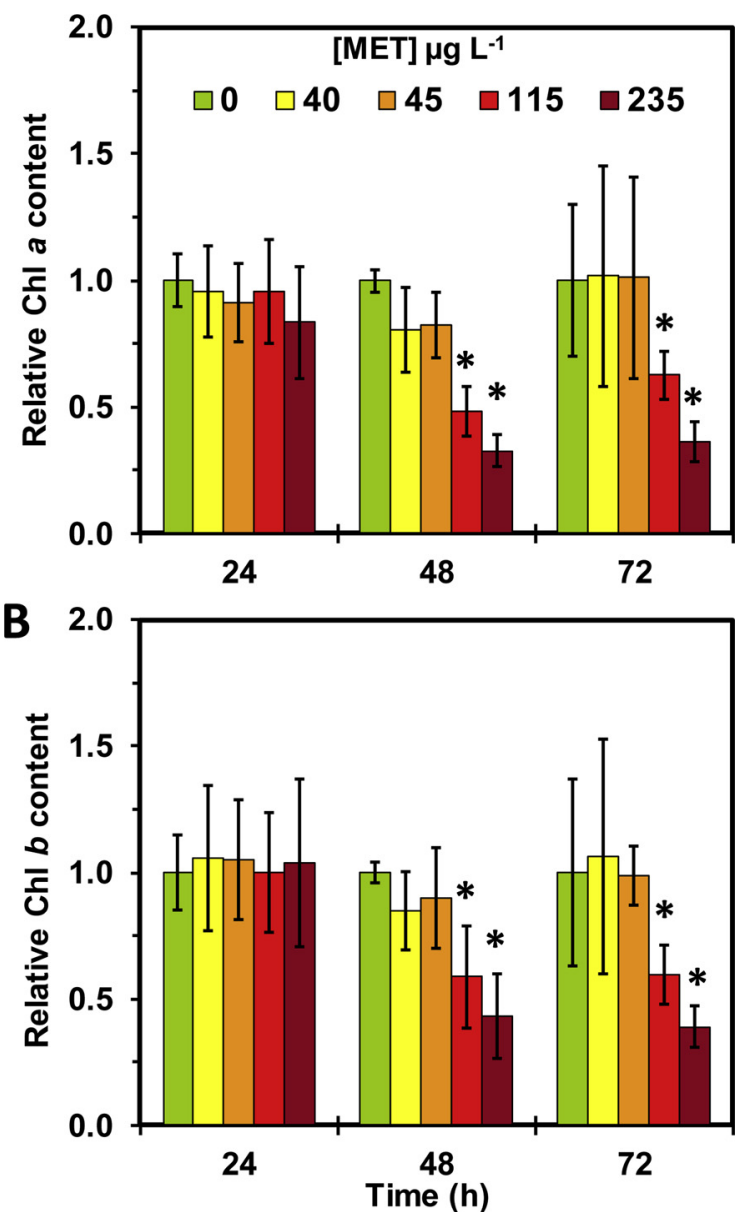

Fig. 3. Influence of MET on photosynthetic pigments of P. subcapitata. A Chlorophyll $a$ (Chl $a$ ) content. B - Chlorophyll $b(\mathrm{Chl} b$ ) content. The provided values are relative to the average of the control (algal cells not treated with MET). The error bars represent the SD. Asterisk denotes significant differences (for a given incubation time) with respect to control according unpaired $t$ test $(P<0.05)$

The cellular content of Chl $a$ in algae exposed, up to $72 \mathrm{~h}$, to MET concentrations $\leq 45 \mu \mathrm{g} \mathrm{L}^{-1}$ was not modified (Fig. 3A). However, algal cells exposed for $48-72 \mathrm{~h}$ to herbicide concentrations of 115 or $235 \mu \mathrm{g}$ $\mathrm{L}^{-1}$ showed a significant reduction of Chl $a$ level (Fig. 3A). A similar pattern was observed when the Chl $b$ pigment was evaluated (Fig. 3B).

The assessment of algae photosynthetic performance revealed a significant reduction of $\mathrm{Fv} / \mathrm{Fm}$ of the cells exposed to 115 or $235 \mu \mathrm{g} \mathrm{L}^{-1}$ MET for 48-72 h (Fig. 4A); this quotient indicates the maximum light utilization efficiency of the PSII and is a sensitive indicator of the photosynthesis performance (Maxwell and Johnson, 2000). The reduction of $\mathrm{Fv} / \mathrm{Fm}$, was accentuated with the increaseof MET concentration and exposure time (Fig. 4A). Algal cells non-exposed to a toxicant (control) exhibited a $\mathrm{Fv} / \mathrm{Fm}$ value of $0.63 \pm 0.04$, which is within the values (0.62-0.64) usually founded in algae (Van der Grinten et al., 2010). The determination of $\phi_{\text {PSII }}$, which measures the fraction of absorbed quantum by chlorophyll in PSII that is used in photochemistry (Maxwell and Johnson, 2000), revealed a similar reduction pattern (Fig. 4B); these results indicated that algal cells exposed for $48-72 \mathrm{~h}$ to 115 or $235 \mu \mathrm{g} \mathrm{L}{ }^{-1}$ MET presented a decreased light utilization efficiency. In addition, it was also observed a reduction of ETR in algal cells exposed for 48-72 h to 115 or $235 \mu \mathrm{g} \mathrm{L}{ }^{-1}$ MET (Fig. 4C). ETR constituted an estimation of the electrons flow rate through the photosynthetic chain (Consalvey et al., 2005). The reduction of ETR in algal cells exposed to $235 \mu \mathrm{g} \mathrm{L}{ }^{-1}$ MET enhanced with the increase of the exposure time to the herbicide (Fig. 4C). Compatible with the loss of photosynthetic efficiency detected, a significant increase of NPQ was observed, when algal cells were exposed for $72 \mathrm{~h}$ to 115 or $235 \mu \mathrm{g} \mathrm{L}{ }^{-1}$ MET (Fig. 4D). NPQ has been seen as a compensatory mechanism of cells to divert some of the energy (through heat or other methods) not converted into chemical energy due to photosynthesis inhibition (Consalvey et al., 2005). Thus, the results here obtained suggest that NPQ processes were activated in cells exposed to the herbicide, in order to dissipate the excess of light energy.

\subsection{MET disturbs algae metabolic activity}

It is known that MET interferes with diverse enzymes to inhibit plant growth (Rose et al., 2016). The esterasic (metabolic) activity of the algal cells exposed to MET was studied through the quantification of the hydrolysis of FDA; the green fluorescence signal presented by algae loaded with FDA can be correlated with their esterasic activity (metabolic activity) (Machado and Soares, 2013).

The exposure of algal cells to MET, for $24 \mathrm{~h}$, induced an increase of the mean value of the green signal emitted by algal cells, indicating a stimulation of the esterasic activity (Fig. 5). Even for algal cells incubated at the lowest MET concentration $\left(40 \mathrm{\mu g} \mathrm{L}^{-1}\right)$, where no change of growth was observed, the esterasic activity increased $48 \%$ after $24 \mathrm{~h}$, when compared to control. The esterasic activity was reduced to levels similar to the control, after the incubation of algal cells for $48 \mathrm{~h}$ with $40-45 \mu \mathrm{g} \mathrm{L}^{-1}$ MET (Fig. 5). Algal cells exposed to $\geq 115 \mu \mathrm{g} \mathrm{L}{ }^{-1} \mathrm{MET}$, for $48-72 \mathrm{~h}$, exhibited a significant reduction of the metabolic activity (Fig. 5).

To exclude a possible influence of MET on FDA-assay, abiotic controls, without algal cells, were carried out. It was observed that MET did not interfere with FDA hydrolysis (Fig. S2A) or with fluorescein fluorescence (Fig. S2B).

\section{Discussion}

MET, a world widely applied herbicide, presents high solubility in water being easily leaked from soil to water bodies where it persists. Its frequent detection in the aquatic environment, mobility and persistence contributed to MET be considered a compound of emerging concern (Fairbairn et al., 2016). The presence of MET concentrations higher than $100 \mu \mathrm{g} \mathrm{L}^{-1}$ in aquatic systems is intermittent, in pulses, as result of herbicide application and of its leaching from soil to runoff water (Boxall et al., 2013). Thus, non-target organisms in water bodies, close to MET agricultural applications, are exposed to fluctuating concentrations of MET. The effect of pulse exposure of MET on the alga $S$. vacuolatus was previously described (Copin et al., 2016; Vallotton et al., 2008).

In the present work it was observed that for $45 \mu \mathrm{g} \mathrm{L} \mathrm{L}^{-1}$ MET, the herbicide reduces algal growth yield without modification of cell biovolume (Fig. 1B), Chl $a$ or Chl $b$ pigments (Fig. 3) or photosynthetic activity (Fig. 4). Cells exposed to $40-45 \mu \mathrm{g} \mathrm{L} \mathrm{L}^{-1}$ of MET presented metabolic (esterasic) activity transiently disturbed (Fig. 5).

The exposure of $P$. subcapitata to 115 or $235 \mu \mathrm{g} \mathrm{L}^{-1}$ MET had as consequence a reduction of algal growth yield to 50 or $90 \%$, an increase of mean biovolume and a modification of algal morphology (Fig. 1). The last effects were particularly evident for $235 \mu \mathrm{g} \mathrm{L}^{-1}$ MET where the growth was arrested (after an exposure to the herbicide for $24 \mathrm{~h}$ ), the mean algal volume raised 8 times (after $72 \mathrm{~h}$ ) (Fig. 1B), and the typical algae shape (cells lunate or helically twisted) changed to French croissant"-type (Fig. 1C). An increase of biovolume was also described for algae $S$. vacuolatus (Vallotton et al., 2008; Copin et al., 2016) and C. reinhardtii (Korkaric et al., 2015) when exposed to MET concentration higher than those used in the present study ( $>450 \mu \mathrm{g} \mathrm{L}^{-}$ $\left.{ }^{1}\right)$.

The increase of biovolume and modification of cell shape in algae 

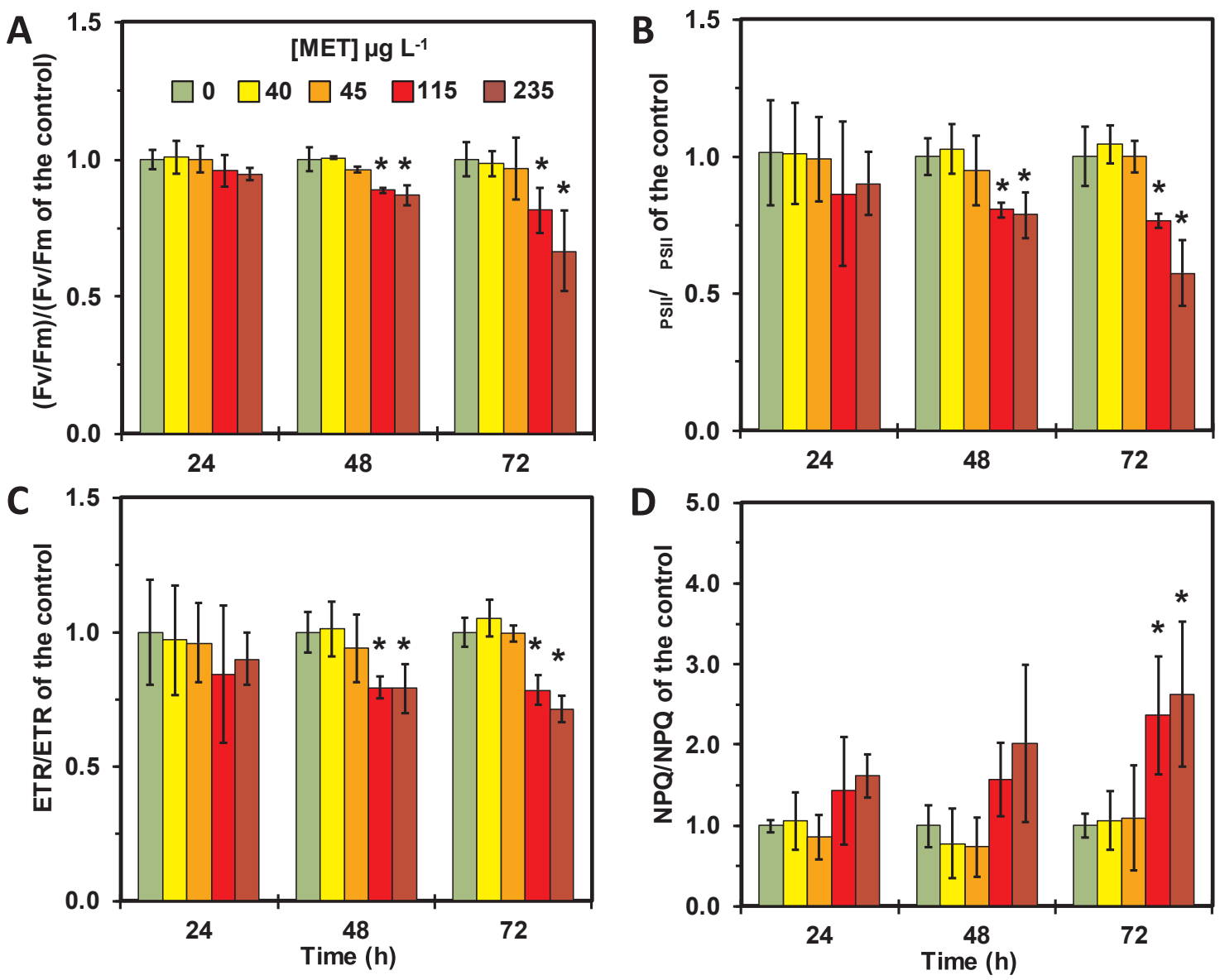

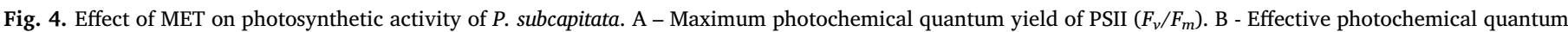

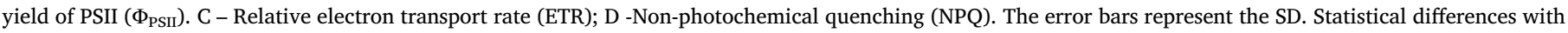
control were subject to unpaired $t$ test; the results with asterisks are significantly different (for a give incubation time) from the control $(P<0.05)$.

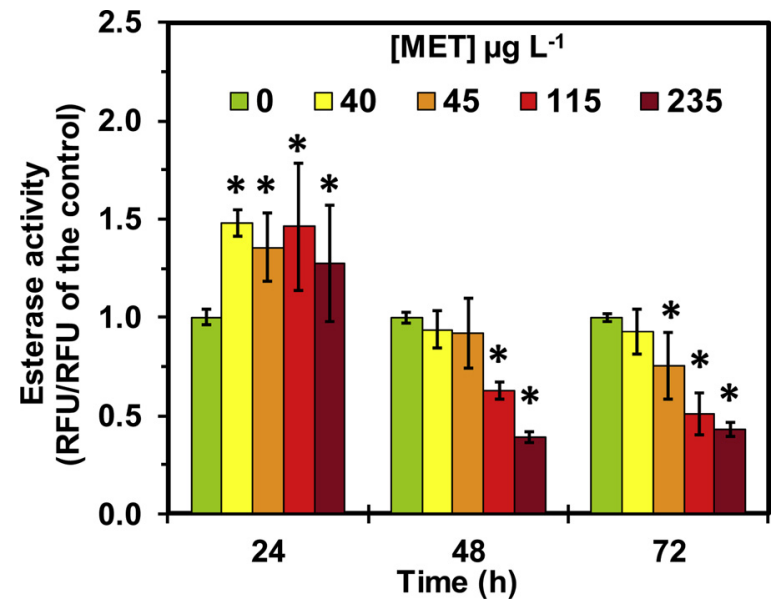

Fig. 5. Repercussion of MET on metabolic activity of $P$. subcapitata. Algal metabolic activity was estimated through the hydrolysis of fluorescein diacetate. The error bars represent the SD. Asterisk denotes significant differences with respect to control (for a given incubation time) according unpaired $t$ test $(P<0.05)$.

exposed to $\geq 115 \mu \mathrm{g} \mathrm{L}{ }^{-1}$ MET was accompanied by an accumulation of multinucleated cells ( $\geq 4$ nuclei) (Fig. S1). These results suggested that MET did not impair nuclear division. The accumulation of multinucleated cells seems to be the consequence of the incapacity of the parent cell to release the autospores when MET, at $\geq 115 \mu \mathrm{g} \mathrm{L}^{-1}$, is present. This effect can be due to a modification of the rigidity of the parental cell wall or to the inhibition of the enzymes associated with the rupture of the wall and release of the autospores in algae treated with MET. This possibility is compatible with the fact that nuclear division and release of autospores are temporally separated during cell reproductive cycle (Pickett-Heaps, 1970). On the other hand, the disturbance of the normal reproductive cycle progression may be in the origin of growth slowdown and growth arrest observed in algal cells exposed to $\geq 115 \mu \mathrm{g} \mathrm{L}{ }^{-1} \mathrm{MET}$. The disturbance of cell growth through the impairment of autospores release was also observed in algae $S$. vacuolatus (Vallotton et al., 2008) and S. acutus (Weisshaar and Böger, 1987) using a different approach: when the algae (previously exposed to MET) were re-inoculated in culture medium without MET they were able to recover the growth.

Chlorophyll is an ubiquitous pigment being very important in photosynthetic organisms, like algae. Chlorophyll biosynthesis involves two different biochemical pathways: the tetrapyrrole (produces the chlorin ring) and the methylerythritol phosphate (responsible for the isoprenoid phytol tail of chlorophyll) pathways (Kim et al., 2013). The exposure of algal cells to 115 or $235 \mu g \mathrm{~L}^{-1} \mathrm{MET}$, for $48 \mathrm{~h}$ or $72 \mathrm{~h}$, induced a reduction of chlorophylls compared to control (Fig. 3). The reduction of chlorophyll content in algae exposed to MET can be a consequence of pigment synthesis inhibition or degradation. A decrease in Chl $a$ and $\mathrm{Chl} b$ concentration was also observed in the microalgae $C$. pyrenoidosa (Liu and Xiong, 2009), Parachlorella kessleri (Maronic et al., 2018) and S. obliquus (Liu et al., 2017) when exposed to MET.

In the present work, it was also observed that cells exposed to 115 or $235 \mu \mathrm{g} \mathrm{L}^{-1} \mathrm{MET}$, for $48 \mathrm{~h}$ or $72 \mathrm{~h}$, presented a reduction of the photosynthetic efficiency traduced by a decrease of $F_{V} / F_{M}$ (Fig. 4A), which indicates a reduction of the maximum capacity of algae to convert light 
into chemical energy. It is widely accepted that $F_{v} / F_{m}$ ratio can be used as valuable parameter to evaluate the extent of photosynthesis photo inhibition (Maxwell and Johnson, 2000). When incubated for $72 \mathrm{~h}$ with these MET concentrations, algal cells also presented a reduction of $\Phi_{\text {PSII }}$ (Fig. 4B), which show a decrease of the efficiency of the PSII photochemistry (Maxwell and Johnson, 2000). Together, these results point to a reduction of the photosynthetic efficiency in algal cells exposed to MET. This disturbance of photosynthesis seems to be associated to a disorder of the electron transport in the photosynthetic chain, as revealed by the reduction of ETR parameter (Fig. 4C). MET, as a chloroacetamide herbicide, inhibits the elongation of fatty-acid species and the synthesis of isoprenoids (Fuerst, 1987; Böger, 2003). It was suggested that this herbicide can affect the photsynthetic activity on algal cells by a secondary (indirect) mechanism, i.e., affecting the structural state of photosynthetic membrane through the impairment of protein and lipid synthesis (Juneau et al., 2001). In parallel with the reduction of photosynthetic efficiency, it was observed a significant increase of NPQ in algae exposed for $72 \mathrm{~h}$ to 115 or $235 \mu \mathrm{g} \mathrm{L}-1$ MET (Fig. 4D), which can be seen as a compensatory way of the cells to dissipate the energy not channelled to photochemical pathway, in an attempt process to preserve the cell photosynthetic apparatus (Consalvey et al., 2005). The results presented here are in agreement with the literature, which describe that the exposure to MET induce a reduction of chloroplasts size in S. obliquus (Liu et al., 2017) and the photosynthesis inhibition (reduction of $\Phi_{\mathrm{PSII}}$ ) in C. reinhardtii (Korkaric et al., 2015).

Esterases are common enzymes in viable cells directly associated with cellular growth and respond to changes in metabolic activity. The exposure of $P$. subcapitata for 48 or $72 \mathrm{~h}$ to MET concentrations of $115-235 \mu \mathrm{g} \mathrm{L}^{-1}$ led also to a reduction of esterase activity (Fig. 5), which suggests a more global disturbance of the enzymatic activity.

In conclusion, the present work studied, for the first time, the impact of MET, over time (up to $72 \mathrm{~h}$ ), at environmental significant levels, on relevant cell targets of the alga $P$. subcapitata. Algae exposed to $45 \mu \mathrm{g}$ $\mathrm{L}^{-1} \mathrm{MET}$, for $72 \mathrm{~h}$, displayed a reduction of growth yield and a transient disturbance of metabolic activity. At concentrations of 115 or $235 \mu \mathrm{g} \mathrm{L}$ 1 , MET induced a reduction of growth yield, metabolic activity, concentration of photosynthetic pigments and photosynthetic efficiency of algal cells. The last disorder seems to be associated with the perturbation of the electron transport in the photosynthetic chain. MET also induced the increase of biovolume and the modification of the alga cell shape. In addition, algal population treated with $\geq 115 \mu \mathrm{g} \mathrm{L}{ }^{-1}$ MET was composed, mainly, by cells with 4-8 nuclei, which indicate an hinderance of the normal progression of the reproductive cycle, without impairment of nuclear division. The incapacity of the parent cells to release the autospores can explain the slowdown (or even the arrest) of growth, the increase of biovolume and the modification of cell shape in algae treated with higher MET concentrations. The present work contributes to the understanding and elucidation of the MoA of MET in the freshwater alga $P$. subcapitata, a non-target organism. The information here obtained can be useful in the risk assessment of chemicals in the environment through the search of more sensitive endpoints or in the development of theoretical models for predicting algal growth inhibition.

\section{CRediT authorship contribution statement}

Manuela D. Machado: Conceptualization, Validation, Formal analysis, Investigation, Writing - original draft, Visualization. Eduardo V. Soares: Conceptualization, Validation, Writing - review \& editing, Visualization, Supervision.

\section{Declaration of Competing Interest}

The authors declare no conflict of interest.

\section{Acknowledgments}

This study was supported by the Portuguese Foundation for Science and Technology (FCT) under the scope of the strategic funding of UID/ BIO/04469/2020 unit and BioTecNorte operation (NORTE-01-0145FEDER-000004) funded by the European Regional Development Fund under the scope of Norte2020 - Programa Operacional Regional do Norte.

\section{Appendix A. Supplementary data}

Supplementary material related to this article can be found, in the online version, at doi:https://doi.org/10.1016/j. aquatox.2020.105449.

\section{References}

Battaglin, W.A., Furlong, E.T., Burkhardt, M.R., et al., 2000. Occurrence of sulfonylurea, sulfonamide, imidazolinone, and other herbicides in rivers, reservoirs and ground water in the Midwestern United States, 1998. Sci. Total Environ. 248, 123-133. https://doi.org/10.1016/S0048-9697(99)00536-7.

Böger, P., 2003. Mode of action for chloroacetamides and functionally related compounds. J. Pestic. Sci. 28, 324-329. https://doi.org/10.1584/jpestics.28.324.

Boxall, A.B.A., Fogg, L.A., Ashauer, R., et al., 2013. Effects of repeated pulsed herbicide exposures on the growth of aquatic macrophytes. Environ. Toxicol. Chem. 32, 193-200. https://doi.org/10.1002/etc.2040.

Campanella, L., Cubadda, F., Sammartino, M.P., et al., 2001. An algal biosensor for the monitoring of water toxicity in estuarine environments. Water Res. 35, 69-76. https://doi.org/10.1016/S0043-1354(00)00223-2.

Chen, S., Zhang, L., Chen, H., et al., 2019. Enantioselective toxicity of chiral herbicide metolachlor to Microcystis aeruginosa. J. Agric. Food Chem. 67, 1631-1637. https:// doi.org/10.1021/acs.jafc.8b04813.

Consalvey, M., Perkins, R.G., Paterson, D.M., et al., 2005. Pam fluorescence: a beginners guide for benthic diatomists. Diatom Res. 20, 1-22. https://doi.org/10.1080/ 0269249X.2005.9705619.

Copin, P.-J., Perronet, L., Chevre, N., 2016. Modelling the effect of exposing algae to pulses of S-metolachlor: how to include a delay to the onset of the effect and in the recovery. Sci. Total Environ. 541, 257-267. https://doi.org/10.1016/j.scitotenv. 2015.08.154.

Deal, L.M., Hess, F.D., 1980. An analysis of the growth inhibitory characteristics of alachlor and metolachlor. Weed Sci. 28, 168-175. https://doi.org/10.1017/ S0043174500055041.

Deng, L., Senseman, S.A., Gentry, T.J., et al., 2015. Effect of selected herbicides on growth and lipid content of Nannochloris oculata. J. Aquat. Plant Manag. 53, 28-35.

Diepens, N.J., Buffan-Dubau, E., Budzinski, H., et al., 2017. Toxicity effects of an environmental realistic herbicide mixture on the seagrass Zostera noltei. Environ. Pollut. 222, 393-403. https://doi.org/10.1016/j.envpol.2016.12.021.

Ebenezer, V., Ki, J.S., 2013. Quantification of toxic effects of the herbicide metolachlor on marine microalgae Ditylum brightwellii (Bacillariophyceae), Prorocentrum minimum (Dinophyceae), and Tetraselmis suecica (Chlorophyceae). J. Microbiol. 51, 136-139. https://doi.org/10.1007/s12275-013-2114-0.

Fairbairn, D.J., Karpuzcu, M.E., Arnold, W.A., et al., 2016. Sources and transport of contaminants of emerging concern: a two-year study of occurrence and spatiotemporal variation in a mixed land use watershed. Sci. Total Environ. 551-552, 605-613. https://doi.org/10.1016/j.scitotenv.2016.02.056.

Fairchild, J.F., Ruessler, D.S., Carlson, A.R., 1998. Comparative sensitivity of five species of macrophytes and six species of algae to atrazine, metribuzin, alachlor, and metolachlor. Environ. Toxicol. Chem. 17, 1830-1834. https://doi.org/10.1002/etc. 5620170924.

Fuerst, E.P., 1987. Understanding the mode of action of the chloroacetamide and thiocarbamate herbicides. Weed Technol. 1, 270-277. https://doi.org/10.1017/ S0890037X00029729.

Götz, T., Böger, P., 2004. The very-long-chain fatty acid synthase is inhibited by chloroacetamides. Z Naturforsch C 59, 549-553. https://doi.org/10.1515/znc-2004-7818.

Juneau, P., Dewez, D., Matsui, S., et al., 2001. Evaluation of different algal species sensitivity to mercury and metolachlor by PAM- fluorometry. Algae 45, 589-598. https://doi.org/10.1016/S0045-6535(01)00034-0.

Jurado, A., Fernandes, M., Videira, R., et al., 2011. Herbicides: the face and the reverse of the coin. An in vitro approach to the toxicity of herbicides in non-target organisms. In: Kortekamp, A. (Ed.), Herbicides and Environment, Rijeka, Croatia.

Kim, S., Schlicke, H., Van Ree, K., et al., 2013. Arabidopsis chlorophyll biosynthesis: an essential balance between the methylerythritol phosphate and tetrapyrrole pathways. Plant Cell 25, 4984-4993. https://doi.org/10.1105/tpc.113.119172.

Kollman, W., Segawa, R., 1995. Interim report of the pesticide chemistry database. Environmental Hazards Assessment Program. Department of Pesticide Regulation, Sacramento, CA, USA.

Korkaric, M., Behra, R., Fischer, B.B., et al., 2015. Multiple stressor effects in Chlamydomonas reinhardtii - toward understanding mechanisms of interaction between effects of ultraviolet radiation and chemical pollutants. Aquat. Toxicol. 162, 18-28. https://doi.org/10.1016/j.aquatox.2015.03.001.

Liu, H., Xiong, M., 2009. Comparative toxicity of racemic metolachlor and S-metolachlor 
to Chlorella pyrenoidosa. Aquat. Toxicol. 93, 100-106. https://doi.org/10.1016/j. aquatox.2009.04.006

Liu, D., Maguire, R.J., Pacepavicius, G.J., et al., 1995. Microbial transformation of metolachlor. Environ. Toxicol. Water Qual. 10, 249-258. https://doi.org/10.1002/tox. 2530100404.

Liu, H., Xia, Y., Cai, W., et al., 2017. Enantioselective oxidative stress and oxidative damage caused by Rac- and S-metolachlor to Scenedesmus obliquus. Chemosphere 173, 22-30. https://doi.org/10.1016/j.chemosphere.2017.01.028.

Lopez, B., Ollivier, P., Togola, A., et al., 2015. Screening of French groundwater for regulated and emerging contaminants. Sci. Total Environ. 518-519, 562-573. https://doi.org/10.1016/j.scitotenv.2015.01.110.

Maazouzi, C., Coureau, C., Piscart, C., et al., 2016. Individual and joint toxicity of the herbicide S-metolachlor and a metabolite, deethylatrazine on aquatic crustaceans: difference between ecological groups. Chemosphere 165, 118-125. https://doi.org/ 10.1016/j.chemosphere.2016.09.030.

Machado, M.D., Soares, E.V., 2012. Development of a short-term assay based on the evaluation of the plasma membrane integrity of the alga Pseudokirchneriella subcapitata. Appl. Microbiol. Biotechnol. 95, 1035-1042. https://doi.org/10.1007/ s00253-012-4185-y.

Machado, M.D., Soares, E.V., 2013. Optimization of a microplate-based assay to assess esterase activity in the alga Pseudokirchneriella subcapitata. Water Air Soil Pollut. 224, 1358. https://doi.org/10.1007/s11270-012-1358-3.

Machado, M.D., Soares, E.V., 2014. Modification of cell volume and proliferative capacity of Pseudokirchneriella subcapitata cells exposed to metal stress. Aquat. Toxicol. 147, 1-6. https://doi.org/10.1016/j.aquatox.2013.11.017.

Machado, M.D., Soares, E.V., 2019a. Sensitivity of freshwater and marine green algae to three compounds of emerging concern. J. Appl. Phycol. https://doi.org/10.1007/ s10811-018-1511-5.

Machado, M.D., Soares, E.V., 2019b. Impact of erythromycin on a non-target organism: cellular effects on the freshwater microalga Pseudokirchneriella subcapitata. Aquat. Toxicol. 208, 179-186. https://doi.org/10.1016/j.aquatox.2019.01.014.

Maronic, D.S., Camagajevac, I.S., Horvatic, J., et al., 2018. S-metolachlor promotes oxidative stress in greenmicroalga Parachlorella kessleri - a potential environmental and health risk for higher organisms. Sci. Total Environ. 637, 41-49. https://doi.org/10. 1016/j.scitotenv.2018.04.433.

Maxwell, K., Johnson, G.N., 2000. Chlorophyll fluorescence - a practical guide. J. Exp. Bot. 51, 659-668. https://doi.org/10.1093/jexbot/51.345.659.

OECD, 2011. Test No. 201: Freshwater Alga and Cyanobacteria, Growth Inhibition Test. Paris, France. .

Pereira, S.P., Fernandes, M.A.S., Martins, J.D., et al., 2009. Toxicity assessment of the herbicide metolachlor comparative effects on bacterial and mitochondrial model systems. Toxicol. In Vitro 23, 1585-1590. https://doi.org/10.1016/j.tiv.2009.06. 032 .

Pérez, J., Domingues, I., Soares, A.M.V.M., et al., 2011. Growth rate of Pseudokirchneriella subcapitata exposed to herbicides found in surface waters in the Alqueva reservoir (Portugal): a bottom-up approach using binary mixtures. Ecotoxicology 20, 1167-1175. https://doi.org/10.1007/s10646-011-0661-x.

Pickett-Heaps, J.D., 1970. Mitosis and autospore formation in the green alga Kirchneriella lunaris. Protoplasma 70, 325-347. https://doi.org/10.1007/BF01275761.

Quintaneiro, C., Patrício, D., Novais, S.C., et al., 2017. Endocrine and physiological effects of linuron and S-metolachlor in zebrafish developing embryos. Sci. Total Environ. 586, 390-400. https://doi.org/10.1016/j.scitotenv.2016.11.153.

Ritchie, R.J., 2008. Universal chlorophyll equations for estimating chlorophylls $a, b, c$, and $d$ and total chlorophylls in natural assemblages of photosynthetic organisms using acetone, methanol, or ethanol solvents. Photosynthetica 46, 115-126. https:// doi.org/10.1007/s11099-008-0019-7.

Rivard, L., 2003. Environmental Fate of Metolachlor. Environmental Monitoring Branch Department of Pesticide Regulation. Sacramento, CA, USA.

Rose, M.T., Cavagnaro, T.R., Scanlan, C.A., et al., 2016. Impact of herbicides on soil biology and function. In: In: Sparks, D.L. (Ed.), Advances in Agronomy Vol. 136 Academic Press, pp. 133-220.
Roubeix, V., Fauvelle, V., Tison-Rosebery, J., et al., 2012. Assessing the impact of chloroacetanilide herbicides and their metabolites on periphyton in the Leyre River (SW France) via short term growth inhibition tests on autochthonous diatoms. J. Environ. Monit. 14, 1655-1663. https://doi.org/10.1039/c2em10887a.

Sbrilli, G., Bimbi, B., Cioni, F., et al., 2005. Surface and ground waters characterization in Tuscany (Italy) by using algal bioassay and pesticide determinations: comparative evaluation of the results and hazard assessment of the pesticides impact on primary productivity. Chemosphere 58, 571-578. https://doi.org/10.1016/j.chemosphere. 2004.07.012.

Singh, B., Singh, K., 2016. Microbial degradation of herbicides. Crit. Rev. Microbiol. 42, 245-261. https://doi.org/10.3109/1040841X.2014.929564.

Soto, P., Gaete, H., Eliana Hidalgo, M., 2011. Assessment of catalase activity, lipid peroxidation, chlorophyll-a, and growth rate in the freshwater green algae Pseudokirchneriella subcapitata exposed to copper and zinc. Lat. Am. J. Aquat. Res. 39, 280-285. https://doi.org/10.3856/vol39-issue2-fulltext-9.

Souissi, Y., Bouchonnet, S., Bourcier, S., et al., 2013. Identification and ecotoxicity of degradation products of chloroacetamide herbicides from UV-treatment of water. Sci. Total Environ. 458-460, 527-534. https://doi.org/10.1016/j.scitotenv.2013.04.064.

Spoljaric, D., Cipak, A., Horvatic, J., et al., 2011. Endogenous 4-hydroxy-2-nonenal in microalga Chlorella kessleri acts as a bioactive indicator of pollution with common herbicides and growth regulating factor of hormesis. Aquat. Toxicol. 105, 552-558. https://doi.org/10.1016/j.aquatox.2011.08.007.

Sun, J., Liu, D., 2003. Geometric models for calculating cell biovolume and surface area for phytoplankton. J. Plankton Res. 25, 1331-1346. https://doi.org/10.1093/plankt/ fbg096.

Székács, A., Mörtl, M., Darvas, B., 2015. Monitoring pesticide residues in surface and ground water in Hungary: surveys in 1990-2015. J. Chem. 1-15. https://doi.org/10. 1155/2015/717948. ID717948.

Thakkar, M., Randhawa, V., Wei, L., 2013. Comparative responses of two species of marine phytoplankton to metolachlor exposure. Aquat. Toxicol. 126, 198-206. https://doi.org/10.1016/j.aquatox.2012.10.002.

US-EPA, 1995. Reregistration Eligibility Decision for Metolachlor EPA 738-R-95-006. Health Effects Division, Office of Pesticide Programs, U.S. Environmental Protection Agency, Washington DC.

US-EPA, 2012a. Algal Toxicity (OCSPP 850.4500). Ecological Effects Test Guidelines. Pollution Prevention. United States Environmental Protection Agency. EPA 712-C006, Washington, DC.

US-EPA, 2012b. Pesticide Ecotoxicology Database (2000) As Cited in the ECOTOX Database. World-Wide Electronic Publication. U.S. Environmental Protection Agency, Washinghton DC Searched on 9 February 2012. Http://cfpub.epa.gov/ecotox/.

US-EPA, 2019. Draft Ecological Risk Assessment for Registration Review for Metolachlor / S-Metolachlor EPA-HQ-OPP-2014-0772. U.S. Environmental Protection Agency, Washinghton DC. Available: https://www.regulations.gov/document?D = EPA-HQOPP-2014-0772-0028. (Accessed 5 December 2019).

Vallotton, N., Moser, D., Eggen, R.I.L., et al., 2008. S-metolachlor pulse exposure on the alga Scenedesmus vacuolatus: effects during exposure and the subsequent recovery. Chemosphere 73, 395-400. https://doi.org/10.1016/j.chemosphere.2008.05.039.

Van den Hoek, C., Mann, D.G., Jahns, H.M., 1997. Chlorophyta: Class 2. Chlorophyceae, Algae: An Introduction to Phycology. Cambridge University Press, Cambridge, UK, pp. 349-390.

Van der Grinten, E., Pikkemaat, M.G., van den Brandhof, E.-J., et al., 2010. Comparing the sensitivity of algal, cyanobacterial and bacterial bioassays to different groups of antibiotics. Chemosphere 80, 1-6. https://doi.org/10.1016/j.chemosphere.2010.04. 011.

Velisek, J., Stara, A., Zuskova, E., et al., 2019. Effects of s-metolachlor on early life stages of marbled crayfish. Pestic. Biochem. Physiol. 153, 87-94. https://doi.org/10.1016/j. pestbp.2018.11.007.

Woodward, E.E., Kolpin, D.W., Zheng, W., et al., 2019. Fate and transport of nitrapyrin in agroecosystems: occurrence in agricultural soils, subsurface drains, and receiving streams in the Midwestern US. Sci. Total Environ. 650, 2830-2841. https://doi.org/ 10.1016/j.scitotenv.2018.09.387. 